\title{
Analysis on Current Application of Accounting Information for Listed Companies in China
}

\author{
Jing $\mathrm{Wu}$ \\ School of Institute of Economics and Management Jiangsu University of Science and Technology, \\ Zhenjiang 212003, China. \\ hellowujing@126.com
}

Keywords: Accounting information; accounting information users.

\begin{abstract}
Accounting information refers to the data valuable to investors which may influence the behavior of investors. It is the economic information of corporate value movements, which reflects the investor's right to know and the right of speech. It usually tends to study the usage of accounting information in China from the perspective of supply, but the quality of corporate accounting information is determined by the game between information supplier and demander. In this case, the requests of accounting information users are ignored, so the significance is lost to emphasize reliability and relevance of accounting information. This paper mainly describes the usage of accounting information of listed companies in China by external information users.
\end{abstract}

\section{Introduction}

It is believed by the information founder Shannon that "Information is used to eliminate the random uncertainty", while information is considered to be the effective data for decision-making in economics. The key to play the role of rational allocation of resources in market lies in the effectiveness of the market, namely the effectiveness of information, and that the investors may accurately determine their investment behaviors in the guidance of effective information. The effective market is defined by Fama as whether the stock price may make a timely, full and complete response when the investors grasp a certain type of information [1]. The so-called effective response refers to that the immediately change at an appropriate magnitude when the investors get such information if an information is released to affect the stock price. In this case, the investors shall neither over-react, nor under-react [2]. It can be seen that the premise of effective market is that the investors get the timely, full and complete accounting information, but what kind of accounting information is really required by investors, and how such accounting information shall be disclosed?

Accounting information may comprehensively reflect the business results, financial position and cash operation. External stakeholders may understand and monitor the enterprise business, management and investment activities through the accounting information provided by enterprises, and the quality of accounting information affects the extent to which the accounting information is useful for decision-making by external stakeholders. It is shown by the research on relationship between quality of accounting information and investment efficiency of enterprises that, high-quality accounting information may effectively supervise the managers and shareholders, and improve the efficiency of investment [3]. According to the views of Decision Usefulness Theory, accounting information will satisfy the decision-making requirements of information users as long as it reaches a certain quality; there are two quality indicators measuring the extent of decision usefulness, and they are relevance and reliability. In the Declaration of Financial Accounting Concept (No. 2) (SFAC2), the relevance is defined by FASB as follows: "Information may help users to predict the endings of past, current and future matters, or to confirm and correct the previous expectations, thus influencing their decision-making ability." In addition, reliability refers to that the accounting information users may trust the information provided by the makers of financial reports, and the accounting information will be considered reliable on when the accounting information may withstand the verification by truly expressing the actual economic activities and results, neither making for the predetermined results nor catering to the needs of a particular interest group [4]. Therefore, it is of no significance to 
discuss information supply in the absence of information users. However, there are still many problems in the use of accounting information in China, which are caused by the limitations of subjective factors or the influence of objective factors, all seriously preventing the improvement of accounting information. This paper mainly studies the use of accounting information of listed companies in China, discusses the causes of these conditions, and finally puts forward corresponding suggestions for improvement.

\section{The Subjective Factors Which Affect the Application of Accounting Information for Listed Companies in China}

With respect to the so-called subjective factors, the behaviors of accounting information users in the existing economic environment are analyzed from the perspective of themselves. This paper mainly discusses two subjective factors: the effective demand subject of accounting information, and the heterogeneous beliefs. The two parts analyze the accounting information users in China from quantity and quality respectively.

\subsection{The Lack of Effective Demand Subject of Accounting Information.}

Effective demand subject of accounting information. Theoretically, the quality of accounting information is the final game outcome between supply and demand, which is not only the process to realize certain interest balance, but also the process in which the demand and supply of accounting information quality are reaching each other gradually [5]. Information supply will never satisfy users in case of ignoring the information demand. As a kind of balance power, the effective demand subject shall have the following elements: (1) Strong market-oriented demand power; (QQuick and efficient information feedback mechanism; (3) Mature information user groups.

Analysis on current situation of effective demand subject of accounting information. From the perspective of elements to be equipped by the effective demand subject of information, this paper discusses the market-oriented demand power, information feedback mechanism, and information user groups, and analyzes the current usage situation of information in China.

Market-oriented demand power. Suppliers may obtain economic benefits by providing general merchandises, so the suppliers take the initiatives of creation demand and guidance demand, and the innovation of supply and the improvement of demand level together become the motive force for the development of commodity market [5]. However, accounting information is a special commodity, and the existing accounting information mainly presents the characteristics of public goods in China, so the suppliers fail to obtain direct economic benefits from the supply of accounting information. Therefore, the information suppliers lack the initiatives of creation demand and guidance demand, and thus make the disconnection of supply and demand of accounting information.

At present, China's market economy system is independently operated by different main market players, and a certain interest balance is reached by an "invisible hand", so government is the largest user of accounting information; on the other hand, government is the maker of accounting standards. The overlap of such economic function and administrative power makes the government inevitably involve in the administrative intervention while conducting macroeconomic regulation and control on market economy, which causes the economic behavior of government free from market economy, and the obscure boundary of regulations and policies.

Information feedback mechanism. As the primary quality index "relevance" to measure the degree of decision usefulness, the feedback mechanism of accounting information plays an important role in the effective implementation of accounting control. Any useful accounting information feedback will reduce the uncertainty of the information users, or prove the correctness, or prompt the user to adjust their expected values or change their behaviors and methods, so as to achieve the desired expectation or minimize adverse effects of those enforced decisions.

Under the premise of the effective market economy, the effective feedback of information and the efficient allocation of resources may be realized by relying on the laws of value and the interests orientation of investors. However, the imperfect market economic system and the interference of various uncertain factors have blocked and twisted the market information transmission and feedback 
functions, and made it impossible to feed back the accounting information to each user timely, reliably and fairly, thus leading to the asymmetry of accounting information. From the development practices of securities market in China, minority shareholders account for the vast majority of the total number of investors, and they are the key forces to maintain the market liquidity, and to promote the healthy market development. However, minority shareholders are often in a weak position in securities transactions, and they mainly acquire data through financial reports and other public accounting information due to the few amount of holding shares. In addition, the delay or embezzlement of such accounting information makes it difficult to guarantee the interests of minority shareholders.

Information user groups. Market needs high-quality information supply, but high-quality information supply needs to be carried by a mature demand system. In China, the existing user groups of accounting information are relatively immature, and investors (especially minority investors) generally lack professional knowledge, most of whom tend to speculation rather than investment, prefer the inside news to the accounting information, and lack the awareness of self-judgment and risk aversion. When the listed companies are suspected of false accounting information and stock speculation, those immature information user groups fail to make a judgment through their own knowledge on accounting professional and enterprise management, and easily suffer from loss. There are four reasons: first of all, the minority investors and even some big investors don't have professional accounting knowledge and management knowledge, the can't fully understand the high quality accounting information; secondly, we are lack of mature financial analysts, securities analysts, institutional investors, so the investors can't be given suggestions objectively and fairly; thirdly, the low maturity of accounting information user groups in China prevent them from providing more professional and detailed requirements on accounting information, which also limits the development of accounting information supply system in a certain extent; fourthly, the accounting information user groups in China lack the autonomous consumption consciousness, and become passive in both the information acquisition and feedback. They prefer "hearsay" and "gossip", so it is impossible to form a force able to compete with information suppliers. In this way, they fail to reflect their own points of view, or put forward their requests.

\subsection{Impact of Heterogeneous Beliefs on the Application of Accounting Information.}

Heterogeneous information refers to difference in valuation ability and level of investors to use accounting information, or the divergence and discrepancy in views of investors on accounting information in the valuation process. Specifically, there is a discrepancy in the ability of different investors to understand and analyze accounting information, so the investors usually make different judgments on the income distribution in the same holding period [6]. The heterogeneous beliefs of investors are mainly formed in three environments: (1) different political and economic system; (2) same political system and market, different information environment; (3) different year. We mainly consider about the second and third point. The heterogeneous beliefs of investors based on accounting information will inevitably lead to the difference in value relevance; however, the difference in value relevance of accounting information is the alienation product of investors' behaviors [7]. Under the existing information environment in China, the rationality of different types of investment enterprises causes the heterogeneous beliefs of investors. For example, upon the promulgation of new accounting standards, there are differences in the analysis of fair value of listed companies among different investment enterprises. Therefore, when fair value is used as valuation variables to conduct information valuation by investors, there is a significant difference in subjective weight, thus affecting the information evaluation. For minority investors, the single channel to acquire information makes them rely too much on the accounting information, which leads to the increase of the degree of information asymmetry and causes heterogeneous beliefs.

\section{The Objective Factors Which Affect the Application of Accounting Information for Listed Companies in China}


With respect to the so-called objective factors, such external environment factors are analyzed as to influence the behaviors of accounting information users in the existing economic environment. This paper mainly discusses three objective factors: the credit crisis of information supply, the beneficiary and buyer of audit service, and the disclosure system of accounting information in China.

\subsection{Impact of Credit Crisis on the Application of Accounting Information.}

Subject to the continuous economy development, China continues to make efforts to reform and improve its accounting system. The frequent occurrence of financial fraud scandal has reduced the trust of accounting information user on capital market and accounting industry, and the accounting credit crisis caused hereby seriously influence the healthy development of the whole industry, thus causing the increased cost of social transaction, blocked economic operation and confused order.

Externally, credit crisis occurs because the accounting firms fail to form effective mechanism to consciously reject false accounting information in the existing environment in China, and the fundamental reason is that the government is dominated by the audit demand of accounting information rather than the internal market demand. China will reform the stock issuance and registration system from March 1, 2016, and at that time the regulation authority will not be required to conduct substantive audit on issuance object. This move will make the audit service in China more market-oriented and conform to the internal market demands, thus reducing the occurrence risk of credit crisis in root.

\subsection{The Separation of Beneficiaries and Purchasers of Audit Services.}

Incorporated enterprises have separated ownership and right of management so that both beneficiaries and purchasers of audit services are also separated. It is the right of shareholders to inquire of management of the company. It is the obligation of the management to provide necessary accounting information. The management should appoint certified public accounts to audit company management for purpose of true and valid accounting information. In Chinese state-controlled listed companies, the management has the absolute power over appointment of a certified public account, and is the purchaser of these audit services. For other listed companies, given the small share proportion of shareholders, the management is not obliged to report to a shareholder. For this reason, the management of a company is a self-restrained individual who has the absolute power over appointment of a certified public account. The audit service of a certified public accountant should be paid and such audit service has the cost. Thus, the management is not only the one audited and but also the purpose of the audit service. In addition, a certified public accountant is also a rational self-interest individual, which may lead to "plight of fraud". Fraud is the result of the balanced competition among accounting firms. It is assumed that accounting firms A and B are competitors. The audited entity A requires falsehood and make-up management of the company during auditing by accounting firm A or accounting firm B. We can find the game as follow:

A

\begin{tabular}{|c|c|c|}
\hline & disclose & fraud \\
\hline disclose & $(0,0)$ & $(0, \mathrm{R})$ \\
\hline fraud & $(\mathrm{R}, 0)$ & $(\mathrm{r}, \mathrm{r})$ \\
\hline
\end{tabular}

$\mathrm{R}$ and $\mathrm{r}$ represent the benefit of the accounting firm, $\mathrm{R}>\mathrm{r}$. The entity A will find another accounting firm when accounting firm A or accounting firm B refuse fraud, and the benefit of accounting firm A or accounting firm B is 0 ; however accounting firm A or accounting firm B will get the same benefit $r$ when they don't refuse fraud. So, the Nash Equilibrium of the game is (fraud, fraud). This reflects that the reason of a single firm will lead to the CPA industry in a "plight of fraud".

Current information supply conditions are analyzed based on these factors: on one hand, when the management holds the actual right to select and appoint a certified public account, it will be impossible for shareholders to select one he/she trusts in to audit the accounting information so that he/she will not give complete reliance on the one appointed by the management for accounting information auditing. On the other hand, presence of the "plight of fraud" in the accountant market leads to insufficient guarantee for utilization of the loopholes in auditing laws and regulations, provision of the audit service that maintains management's interests but do harms to shareholders' 
interests by certified public accountants or even committing fraud deliberately that infringes shareholders' interests together with the governing authority by going against professional ethics of certified public accountants in case of lower auditing risks, even if the management selects a reputed accounting firm for provision of the audit service. As a result, loss of right to select and appoint a certified public accountant by shareholders and the resulting separation between the beneficiary and the purchaser of the audit service lead to loss of trust of shareholders in using the accounting information, fundamentally imposing an impact on use of the accounting information and investment decision making by shareholders.

\subsection{The Disclosure of Accounting Information.}

Financial accounting information and management accounting information. Accounting information may be classified into financial type and management type. Today in China, it is common that the financial accounting information based on accounting standards is regarded as the subject of information disclosure. Most of the analysis results are expressed in the financial accounting information, such as earnings per share, cash flows, etc. However, the financial accounting information falls behind the production and management processes and falls into resulting information [8]. Pure financial accounting information does no help to understanding of the company's internal management decisions or production and business activities by investors. Market players requires not only the accounting information based on accounting standards but also information details that directly reflects drivers of value changes of the company. In contrast, the management accounting information tightly links descriptive explanations with quantified results, with an information effect that is given into play prior to or during implementation of decisions [9]. Independent of the financial accounting process, the management accounting information attaches importance to prediction and decision-making functions, complements deficiencies of pure financial information and enhances transparency of company information and serviceability of accounting information.

Historical cost and fair value. The Ministry of Finance of the People’s Republic of China ("MOF”) introduced fair value measurement in several accounting standards for the first time, this standards are debt restructuring, investment, non-currency exchange. However, lack of the relevant institutional conditions and application of related transactions by several enterprises for accounting fraud forced MOF to delete most contents related to fair value measurement in 2001. For purpose of similar pattern with IASB, MOF declared re-adoption of fair value measurement in July, 2004 and enacted a new accounting standard where held a prudent attitude towards fair value measurement in 2007. The historical costremains a major profile of measurement in existing market conditions in China. However, we should allow for the fixed assets including building construction in China with significantly different actual value from the historical cost. It is hard for accounting information users to determine the true solvency and risk level of a listed company by using its accounting information. Proper disclosure of the fair value helps enhances interpretability of the accounting information and value relevance of accounting earnings of a listed company. Bass's empirical study revealed that fair values of loan, security investment and long-term liability are value-relevant. In particular, the fair value information of loan has more value relevance with share price than the historical cost [10]. Zhangye and Huqian performed an empirical study for the fair value information of financial listed companies in Hong Kong. The results showed that whether the fair value of financial assets or unrealized gains or losses generated by changes in fair value contributed to significant incremental interpretability of stock return or share price [11].

Impact of disclosure of annual reports on information users. The Securities Law regulate that the listed companies shall submit annual reports to stock exchange and the securities regulatory authority under the State Council within 4 months from the end of each accounting year. At present, a large number of listed companies select to disclose their annual reports in the last ten-day period of a month, far larger than the number of companies under pre-contract disclosure. In addition, the disclosure of annual reports in China is of a serious imbalance. In recent years, China's economic growth has slowed down, and the management has the motivation to delay the early delivery of "bad news" to investors, so as to reduce the adverse reactions of the market. 


\section{Summary}

From the perspective of demand, this paper studies the current application of accounting information for listed companies in China. The relationship between supply and demand of accounting information is of dialectical unity, not only a game and competition relationship, but also a correlation and promotion relationship. The supply of accounting information affects the demand, and the demand of accounting information also determines the supply. In this paper, the present situation of listed companies in China is discussed, and the following conclusions are drawn:

First of all, China's market economy is still in development stage, so the cultivation of a group of users who may timely, effectively and accurately apply the accounting information will greatly promote the development of stock market, lower the investor's risk, and reduce the disclosure cost of listed companies; in addition, this group will become the backbone force to monitor the accounting information supply, promote the development of accounting information supply, and enhance the marketization of accounting information supply, thus beating the false accounting information. Finally, the professional knowledge of accounting information users shall be improved. Everyone is a potential investor, so the elementary accounting knowledge shall become a basic discipline, rather than a discipline only understood by accounting professionals.

Secondly, at present, China relies more on the production control and government supervision to manage the false accounting information and to improve the application efficiency of accounting information. In that case, the market force seems to be extremely weak in balancing the information supply and demand relationship and the supervision of information supply. If the securities regulators intervene too much with stock market or replace the investors to conduct substantive audit on listed companies (or replace the investors to make a value judgment), it will stifle the market vitality, increase the reliance of investors on regulators, or even cause corruption of regulators. Therefore, the market vitality shall be fully stimulated to select the superior and eliminate the inferior.

Thirdly, China is in the transition period, and its various economic systems are under constant adjustment. In addition, many listed companies and investors have not formed the market consciousness, and the information disclosure shall have its relevance, reliability, comparability and timeliness improved. At the same time, it will be easy to be understood by investors that the core standard of accounting information supply is to start from the perspective of information users.

\section{References}

[1] Fama, E., French, K., 1992, “The Cross-section of Expected Stock Returns”, Journal of Finance, 47, pp.427-466.

[2] Xianjie Tang, Songtao Ren. Analysis of investor's behavior deviation and Countermeasure [J].Business Research, 2006(4):149-152.

[3] Yunshu Wang. Impact of the quality of accounting information for business investment efficiency [J]. Commodity and Quality Theoretical Research, 2014(9): 112-112.

[4] Zhibo Sun. Relevance and Reliability of Accounting Information [J]. Market Forum, 2006(4):218-219.

[5] Xiaoming Jiang. Accounting Information Distortion [J].Accounting Research, 2003(8):3-7.

[6] Yang Wang. Impact of heterogeneous beliefs on the application of accounting information [J]. Technology and Management, 2010(4).

[7] Zhi Wang. Analysis of heterogeneous beliefs, accounting information and market Efficiency

[M].Beijing: Economic Science Press, 2013: 41-43.

[8] Lan Chen. Discussion about the targeting of Accounting [J]. Financial Economic.2009.1:143-144

[9] Xiang Li, Zheng Feng. Accounting Information Disclosure Demand [J]. Accounting Research, 2006(3): 63-68. 
[10] Barth, M. E., W. R. Landsman and J.M. wahlen. Fair value accounting: effects on banks' earnings volatility, regulatory capital, and value of contractual cash flows [J]. Journal of Banking \&Finance, 1995, 19:577-605.

[11] Ye Zhang, Qin Hu. Content and the fair value of assets [J]. Securities market, 2007(12): 29-35.

[12] Zhengfei Lu, Guohua Jiang. An Empirical Study of Accounting Information and Investment Securities [M].Beijing: China Renmin University Press, 2008: 68-79. 